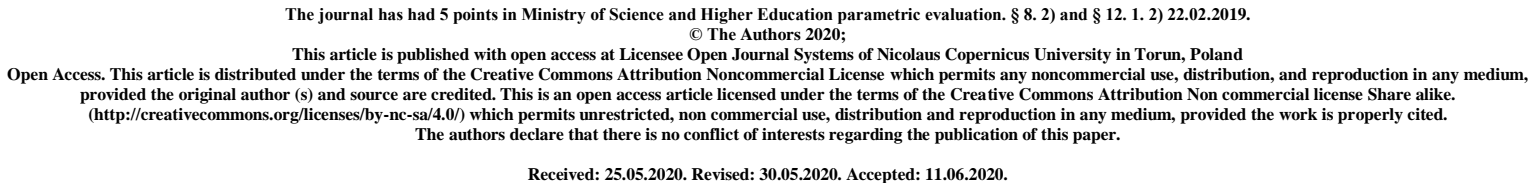

\title{
Prevention, diagnosis and treatment of venous thromboembolism
}

Dominik Machaj dominik5a4@tlen.pl Faculty of Medicine, Medical University of Lublin, Chodźki Street 19, 20-093 Lublin Poland

Katarzyna Cyboran katarzyna_cyboran@o2.pl Medical Faculty, Institute of Medical Sciences, Collegium Medicum, Oleska Street 48, 45-052 Opole Poland

Alicja Placzek alicja60@poczta.onet.pl Medical Faculty, University of Rzeszow, Pigonia Street 6, 35-310 Rzeszow Poland

Marlena Baran mbaran96@gmail.com Medical Faculty, University of Rzeszow, Pigonia Street 6, 35-310 Rzeszow Poland

Michał Wojnowski wojnowski.michal20@gmail.com Medical Faculty, University of Rzeszow, Pigonia Street 6, 35-310 Rzeszow Poland

\begin{abstract}
The formation of a thrombus in a vein leads to a narrowing of its lumen and a reduction in blood flow, which results in the development of venous thromboembolism (VTE). It manifests itself in most cases, including pain, swelling and redness of the affected limb. Data published in 2007 indicate that in 6 European Union countries as many as 370,000 deaths per year are a consequence of deep vein thrombosis (DVT), which is $75 \%$ a consequence of hospitalization. [2] [11] The causes of blood clots are found in the factors of the so-called Virchow triad. The main risk factors for venous thromboembolism as well as its complications of pulmonary embolism include thrombophilia, advanced age, previous VTE, immobilization of trauma or surgery. In the diagnosis of VTE, the determination of D-dimer level plays a key role.
\end{abstract}

Key Words: venous thromboembolism; pulmonary embolism; deep vein thrombosis 


\section{INTRODUCTION AND PURPOSE}

Venous thromboembolism (VTE) is caused by a blood clot in a vein, usually the lower limb, which causes blood to stop in it. Three factors of the Virchow triad contribute to the formation of a blood clot in a venous vessel, i.e. slowing down the flow of blood, the advantage of thrombotic factors over coagulation inhibitors and fibrinolytic factors, and damage to the vessel wall. A fragment of the thrombus can break off and, through the blood stream, get through the right atrium, right ventricle to the pulmonary artery. Very rarely, a complication can be stroke or peripheral embolism. This disease, including deep vein thrombosis and pulmonary embolism, is the most common consequence of it. It is one of the most serious complications of surgical procedures. The main risk factors for its occurrence are age over 40 years, varicose veins of the lower extremities, VTE in the past, injuries, operations, immobilization or paresis of the limb. The course can often be scanty symptomatic or completely asymptomatic. The main symptoms include pain and swelling of the affected limb (difference in circumference of the limbs), its excessive warmth, redness, tenderness, tenderness or dorsal flexion of the foot, tachycardia, fever or fever, and pulmonary embolism, chest pain, fatigue, dry cough sometimes with hemoptysis, loss of consciousness, shock. The risk of developing venous thromboembolism increases with age for both sexes. In the white population of the USA, there are over 200,000 new cases of VTE each year, of which 107,000 are deep vein thrombosis alone, and 94,000 is pulmonary embolism (with or without deep vein thrombosis). [1] Additional cases should be kept in mind that the non-white population was not included in the study above due to the demographic structure of the Olmsted County population in which the study was conducted. This review aims to gather symptoms, methods of diagnosis and treatment of venous thromboembolism.

\section{DESCRIPTION OF THE STATE OF KNOWLEDGE}

Thrombophilia is one of the factors disturbing the balance between coagulation inhibitors and fibrinolytic factors and pro-coagulant factors. Their division according to the risk of thrombotic incident is presented in Table 1 [2], while the factors of congenital thrombophilia are presented in Table 2 [3]. 


\begin{tabular}{|c|c|}
\hline & Thrombophilia \\
\hline \multirow[t]{3}{*}{ Low risk factors } & $\begin{array}{c}\text { heterozygous forms of the Leiden G1691A } \\
\text { mutation factor V gene and G20210A } \\
\text { polymorphism of the prothrombin gene }\end{array}$ \\
\hline & protein $\mathrm{C}$ deficiency \\
\hline & S protein deficiency \\
\hline \multirow{4}{*}{ High risk factors } & $\begin{array}{l}\text { homozygous forms of the Leiden G1691A } \\
\text { mutation of the factor V gene and G20210A } \\
\text { polymorphism of the prothrombin gene }\end{array}$ \\
\hline & $\begin{array}{l}\text { coexistence of heterozygous forms of these } \\
\text { two mutations }\end{array}$ \\
\hline & antithrombin deficiency \\
\hline & $\begin{array}{l}\text { antiphospholipid syndrome (acquired } \\
\text { thrombophilia) }\end{array}$ \\
\hline
\end{tabular}

table1

\begin{tabular}{|c|c|c|}
\hline Established genetic factors & Rare genetic factors & Indeterminate factors \\
\hline Factor V Leiden & Dysfibrinogenemias & Elevated Factor VIII \\
\hline Prothrombin G20210A & \multirow[t]{12}{*}{ Hyperhomocysteinemia } & Elevated Factor IX \\
\hline Protein $\mathrm{C}$ deficiency & & Elevated Factor XI \\
\hline Protein S deficiency & & Plasminogen deficiency \\
\hline \multirow[t]{9}{*}{ Antithrombin deficiency } & & $\begin{array}{c}\text { Tissue plasminogen } \\
\text { activator }\end{array}$ \\
\hline & & Elevated lipoprotein a \\
\hline & & Factor VII \\
\hline & & Factor XII \\
\hline & & Platelet glycoprotein \\
\hline & & $\begin{array}{c}\text { Plasminogen activator } \\
\text { inhibitor }\end{array}$ \\
\hline & & Heparin cofactor II \\
\hline & & Thrombomodulin \\
\hline & & Histidine-rich glycoprotein \\
\hline
\end{tabular}

table2

Risk factors due to the likelihood of a thrombotic event can be divided into:

1. factors of high importance: fracture of the proximal femur, arthroplasty of large joints; hip or knee surgery, other major surgery and spinal cord rupture.

2. factors of medium importance: chemotherapy, heart failure, hormone replacement therapy, cancer, hormonal contraception, pregnancy and puerperium, history of VTE, thrombophilia, lower limb surgery

3. factors of low importance: stay in bed over 3 days, old age, arthroscopy, overweight, varicose veins. [4] 
Venous thromboembolism manifests as deep vein thrombosis (DVT) of the lower extremities. Assessment of the likelihood of occurrenceDVT is facilitated by the Wells scale - table 3. [5]

\begin{tabular}{|c|c|}
\hline Clinical feature & number of points \\
\hline $\begin{array}{c}\text { Active cancer } \\
\text { Treatment or palliation within } 6 \text { months }\end{array}$ & 1 \\
\hline $\begin{array}{c}\text { Bedridden recently> } 3 \text { days or major surgery } \\
\text { within } 12 \text { weeks }\end{array}$ & 1 \\
\hline $\begin{array}{l}\text { Calf swelling }>3 \mathrm{~cm} \text { compared to the other } \\
\text { leg } \\
\text { Measured } 10 \mathrm{~cm} \text { below tibial tuberosity }\end{array}$ & 1 \\
\hline $\begin{array}{c}\text { Collateral (nonvaricose) superficial veins } \\
\text { present }\end{array}$ & 1 \\
\hline Entire leg swollen & 1 \\
\hline $\begin{array}{l}\text { Localized tenderness along the deep venous } \\
\text { system }\end{array}$ & 1 \\
\hline Pitting edema, confined to symptomatic leg & 1 \\
\hline $\begin{array}{l}\text { Paralysis, paresis, or recent plaster } \\
\text { immobilization of the lower extremity }\end{array}$ & 1 \\
\hline Previously documented DVT & 1 \\
\hline $\begin{array}{c}\text { Alternative diagnosis to DVT as likely or } \\
\text { more likely }\end{array}$ & -2 \\
\hline
\end{tabular}

table3

If the sum of points obtained is 0 or less probability of presence deep vein thrombosis is small, for 1-2 points intermediate, while for 3 and more large. In studies conducted by PS Wells and co-authors among patients who received 0 points on this scale, DVT developed in $5 \%$ of them, in patients with a score of $1-217 \%$, and for 3 points and more the risk of deep vein thrombosis is as high as 53\%. In $25 \%$ of patients with symptoms strongly suggesting DVT, which were not assessed on the Wells scale, this disease was confirmed by imaging tests [6]. If the probability of the presence of deep vein thrombosis is low, then the concentration of D-dimers should be determined. The correct level allows you to exclude DVT, while increased values may also have another cause, such as cancer, surgery or trauma, and can not be considered confirmation of the diagnosis. However, they oblige to perform imaging tests - ultrasound of the veins of the lower limb. In the case of high probability DVT on the Wells scale, the correct level of D-dimers does not allow to exclude this disease. Antithrombotic prophylaxis should be used if it has not been used so far and an ultrasound of the veins of the lower limb must be performed, which should be repeated within 24-48 hours. If the level of D-dimers is normal and no clot is found by imaging, diagnosis of DVT can be ruled out. However, in the case of elevated D-dimers, imaging tests should be repeated several times on subsequent days. [7] if it is not used so far and it is absolutely necessary to perform an ultrasound of the veins of the lower limb, which should be repeated within 24-48 hours. If the level of D-dimers is normal and no clot is found by imaging, diagnosis of DVT can be ruled out. However, in the case of elevated D-dimers, imaging tests should be repeated several 
times on subsequent days. [7] if it is not used so far and it is absolutely necessary to perform an ultrasound of the veins of the lower limb, which should be repeated within 24-48 hours. If the level of D-dimers is normal and no clot is found by imaging, diagnosis of DVT can be ruled out. However, in the case of elevated D-dimers, imaging tests should be repeated several times on subsequent days. [7]

Pulmonary embolism is strongly associated with DVT. The Wells Scale was also developed to assess the likelihood of pulmonary embolism. It is presented in table 4. [8]

\begin{tabular}{|c|c|}
\hline Clinical feature & number of points \\
\hline Clinical signs and symptoms of DVT & 3.0 \\
\hline PE is \# 1 diagnosis or equally likely & 3.0 \\
\hline Heart rate> 100 & 1.5 \\
\hline $\begin{array}{c}\text { Immobilization at least 3 days OR surgery in } \\
\text { the previous 4 weeks }\end{array}$ & 1.5 \\
\hline Previous, objectively diagnosed PE or DVT & 1.5 \\
\hline hemoptysis & 1.0 \\
\hline Malignancy w / treatment within 6 months \\
or palliative
\end{tabular}

table4

Can be applied in either three tier or two tier models:

Three tier: 0-1: low risk, 2-6: moderate risk,> 6: high risk

Two tier: $\leq 4$ : unlikely, $\geq 4.5$ : likely

Similarly to DVT, the concentration of D-dimers plays an important role in the diagnosis of pulmonary embolism. If the likelihood of PE on the Wells scale is low or moderate, D-dimer levels should be determined. The correct concentration excludes PE. The elevated level requires imaging of the pulmonary artery - preferably angio-CT. If the probability of PE is high, an imaging test should be performed immediately. [7]

\section{CONCLUSIONS}

The main risk factors for venous thromboembolism and pulmonary embolism include, but are not limited to, advanced age, varicose veins of the lower extremities, previous VTEs, injuries, operations, immobilization, hormonal contraception, hormone replacement therapy and thrombophilia. VTE manifests itself in pain, as well as swelling of the affected limb, there is a difference in the circumference of the limbs, excessive warming of the affected limb, redness, tenderness, tenderness. We suspect PE in the case of shortness of breath, chest pain, dry cough, haemoptysis, which occurs in the event of a lung infarction, tachycardia and tachypnoe, fatigue with anxiety, wheezing over the lung fields. Loss of consciousness and shock may also occur.

According to the recommendations of the American Heart Association and the American College of Cardiology, low molecular weight and unfractionated heparin is used to treat venous thromboembolism. Low molecular weight heparin is the first choice drug. [9] [10] 
Its advantage over unfractionated is due to greater bioavailability, longer duration of action, lower percentage of complications and no need to monitor coagulation times.

\begin{tabular}{|l|l|}
\hline heparin & Dosage \\
\hline nadroparin & $\begin{array}{l}0.1 \mathrm{ml} \mathrm{/} \mathrm{10} \mathrm{kg,} \mathrm{every} \mathrm{24} \\
\text { hours }\end{array}$ \\
\hline dalteparin & $\begin{array}{l}100 \mathrm{IU} / \mathrm{kg}, \text { every 12 } \\
\text { hours }\end{array}$ \\
\hline enoxaparin & $1 \mathrm{mg} / \mathrm{kg}$, every 12 hours \\
table5
\end{tabular}

Dosage of low molecular weight heparins in the treatment of venous thromboembolism is presented in Table 5. [10]

\begin{tabular}{|l|l|}
\hline heparin & Dosage \\
\hline nadroparin & $0.3-0.4 \mathrm{ml}$, every 24 hours \\
\hline dalteparin & $\begin{array}{l}2500-5000 \text { units, every 24 } \\
\text { hours }\end{array}$ \\
\hline enoxaparin & $20-40 \mathrm{mg}$, every 24 hours \\
\hline
\end{tabular}

table6

Dosage of low molecular weight heparins for VTE prophylaxis is presented in Table 6. [10] Unfractionated heparin therapy requires monitoring of the value of koalin-cephalin time (APTT). It should be extended by 1.5-2.5 times compared to the value before treatment. If VTE first occurs, it is recommended to use anticoagulants for a minimum of 3, while in the case of recurrent venous thromboembolism, this period should be extended to at least a year.

\section{REFERENCES}

1. Silverstein, MD, Heit, JA, Mohr, DN, Petterson, TM, O'Fallon, WM, \& Melton, LJ (1998). Trends in the incidence of deep vein thrombosis and pulmonary embolism: a 25-year population-based study. Archives of internal medicine, 158 (6), 585-593.

2. Wojtasińska, E. Congenital thrombophilia as a risk factor for venous thromboembolism.

3. Khan, S., \& Dickerman, JD (2006). Hereditary thrombophilia. Thrombosis Journal, 4 (1), 15.

4. Chmielewski, D., Górecki, A., Kusz, D., Małdyk, P., Marczyński, W., \& Tomkowski, W. (2009). Principles of prophylaxis of venous thromboembolism in orthopedics and traumatology of the locomotor system. Orthopedics Traumatology Rehabilitation. Medsportpress, 1 (6), 86-92.

5. Wells, PS, Anderson, DR, Bormanis, J., Guy, F., Mitchell, M., Gray, L., ... \& Lewandowski, B. (1997). Value of assessment of pretest probability of deep-vein thrombosis in clinical management. The Lancet, 350 (9094), 1795-1798. 
6. Wells, P., Hirsh, J., Anderson, D., Lensing, AA, Foster, G., Kearon, C., ... \& Girolami, A. (1995). Accuracy of clinical assessment of deep-vein thrombosis. The Lancet, 345 (8961), 1326-1330.

7. Windyga, J., Podolak-Dawidziak, M., \& Chojnowski, K. (2010). Rules for the diagnosis of venous thromboembolism. Hematology, 1 (2), 93-101.

8. Wells, PS, Anderson, DR, Rodger, M., Ginsberg, JS, Kearon, C., Gent, M., ... \& Bowie, D. (2000). Derivation of a simple clinical model to categorize patients probability of pulmonary embolism: increasing the models utility with the SimpliRED D-dimer. Thrombosis and haemostasis, 83 (03), 416-420.

9. Kearon, C., \& Hirsh, J. (2001). Prevention of venous thromboembolism. Hemostasis and thrombosis. Philadelphia Pa: Lippincott, Williams and Wilkins, 1405-12.

10. Gutknecht, P., Łuszczyńska-Nitka, G., \& Siebert, J. (2007). Venous thromboembolism in the practice of a family doctor. In Family Medicine Forum (Vol. 1, No. 2, pp. 115-124).

11. Cohen, AT, Agnelli, G., Anderson, FA, Arcelus, JI, Bergqvist, D., Brecht, JG, ... \& Mottier, D. (2007). Venous thromboembolism (VTE) in Europe. Thrombosis and haemostasis, 98 (10), 756-764. 